\title{
H1N1 Infection-Related Hemophagocytic Lymphohistiocytosis in a Child
}

\section{H1N1 Enfeksiyonu ile İlişkili Hemofagositik Lenfohistiositoz Saptanan Bir Çocuk Hasta}

\author{
Fatih Demircioğlu1, Elif Kazancı², Dildar Bahar Genç², Hakan Erdoğan², \\ Sevil Bilir Göksügürl, Mervan Bekdaş1 \\ ${ }^{1}$ Medical Faculty, Abant İzzet Baysal University, Department of Pediatrics, Bolu, Turkey \\ ${ }^{2}$ Dörtçelik Children's Hospital, Department of Pediatrics, Bursa, Turkey
}

To the editor,

Hemophagocytic lymphohistiocytosis (HLH) is a clinical condition characterized by macrophage and activated histiocyte proliferation, leading to uncontrolled phagocytosis of hematopoietic precursor cells. The clinical presentation is characterized by fever, pancytopenia, hepatosplenomegaly, and hemophagocytosis in the reticuloendothelial system. In addition to the primary form of the disorder, secondary HLH has been associated with a variety of infections, malignancy, and autoimmune disease [1]. Virus-associated HLH is a well-recognized clinical condition. Most cases are related to Epstein-Barr virus (EBV), cytomegalovirus (CMV), human herpes virus 6, and human herpes virus 8 infections [2]. H1Nl influenza-associated HLH has been reported in children extremely rarely $[3,4]$. We present here a successfully treated case of severe H1N1 influenza-related HLH.

A 4-year-old boy was admitted to our hospital with a 5-day history of fever, malaise, myalgia, cough, respiratory distress, oliguria, and diffuse petechial eruption. On physical examination he was found febrile, pale, and dehydrated. His vital signs included a temperature of 38.7 ${ }^{\circ} \mathrm{C}$, heart rate of 154 beats per minute, respiratory rate of 42 breaths per minute, blood pressure of $79 / 56 \mathrm{mmHg}$, and capillary refill time of $>2 \mathrm{~s}$. He had 6-cm hepatomegaly and 9 -cm splenomegaly below the costal margin. The rest of the physical examination was normal.
Laboratory examination demonstrated hemoglobin of 9.2 $\mathrm{g} / \mathrm{dL}$, white blood cell count of $3000 / \mathrm{mm}^{3}$ (24\% neutrophils, $62 \%$ lymphocytes, and $14 \%$ monocytes), and platelet count of $56,000 / \mathrm{mm}^{3}$. In the peripheral smear investigation, toxic granulation was observed. Biochemical evaluation revealed that blood urea nitrogen was $118 \mathrm{mg} / \mathrm{dL}$, creatinine $1.6 \mathrm{mg} /$ $\mathrm{dL}$, sodium $124 \mathrm{mmol} / \mathrm{L}$, potassium $2.92 \mathrm{mmol} / \mathrm{L}$, C-reactive protein $18.5 \mathrm{mg} / \mathrm{dL}(\mathrm{N}$ : $0.0-1.0 \mathrm{mg} / \mathrm{dL})$, fibrinogen 120 $\mathrm{mg} / \mathrm{dL}$, and ferritin $875 \mathrm{ng} / \mathrm{mL}$. Serum triglycerides were increased to $268 \mathrm{mg} / \mathrm{dL}$ but cholesterol levels were in the normal range. The serum aspartate aminotransferase, alanine aminotransferase, and lactate dehydrogenase levels were elevated at 208, 72, and $893 \mathrm{U} / \mathrm{L}$, respectively. Serologic markers for EBV; CMV; parvovirus B19; toxoplasmosis; hepatitis $\mathrm{A}, \mathrm{B}$, and $\mathrm{C}$ viruses; human immunodeficiency virus, salmonella; and Brucella agglutinins were all negative. Results of the urine analysis were in the normal range. Chest radiograph demonstrated infiltrates in both lung fields and bilateral pleural effusions.

Intravenous fluid replacement and meropenem and dopamine infusion were started. On the second day of hospital admission, H1N1 influenza was identified from nasopharyngeal swabs by specific PCR, and then oseltamivir ( $6 \mathrm{mg} / \mathrm{kg}$ in 2 daily doses, per os) was added to the treatment. HLH was suspected because of the patient's persistent fever, severe pancytopenia, hyperferritinemia, hypertriglyceridemia, hepatosplenomegaly, and

Address for Correspondence: Fatih DEMIRCIOĞLU, M.D.,

Medical Faculty, Abant İzzet Baysal University, Department of Pediatrics, Bolu, Turkey

E-mail: fatih_demircioglu@yahoo.com

Received/Gelis tarihi : January 23, 2013

Accepted/Kabul tarihi : February 4, 2013 


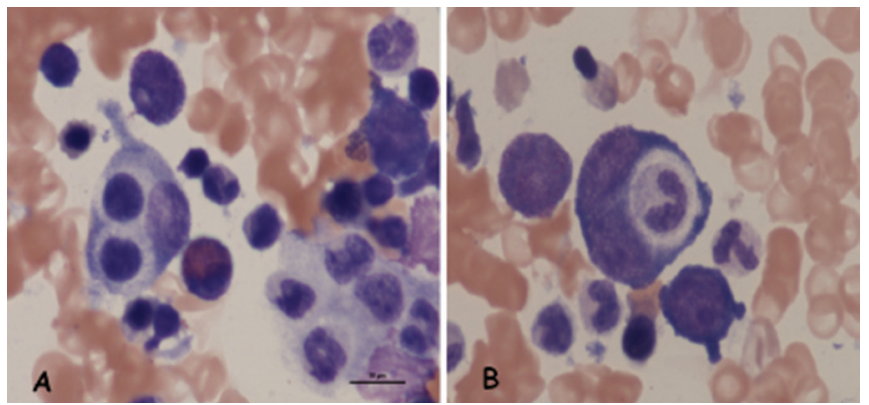

Figure 1: Bone marrow smear shows histiocytes with hemophagocytosis (A and B).

hypofibrinogenemia. A bone marrow aspiration was performed and the results revealed typical hemophagocytosis (Figure 1). Therefore, intravenous immunoglobulin (IVIG) was added to the treatment due to the diagnosis of H1N1associated HLH. Renal functions returned to normal on the second day of treatment. The patient's respiratory function gradually recovered on day 4 . On the third day of oseltamivir and meropenem therapy, the patient became afebrile, and oseltamivir and meropenem therapies were stopped after 5 days and 10 days of treatment, respectively. On the 10th day of admission, physical examination and laboratory evaluation were found normal. He was discharged on day 14. In the first year of follow-up, hematologic and biochemical values were normal, except for moderate splenomegaly and hyperferritinemia (ferritin level was 725 $\mathrm{ng} / \mathrm{mL}$ ). Immunodeficiency, infection, malignancy, and other splenomegaly-related conditions were excluded. Informed consent was obtained.

\section{Discussion}

The H1Nl virus was first observed in March 2009 in Mexico and then spread rapidly throughout the world. Cases of H1N1 have generally been mild, with patients recovering fully within 1 week [5]. Hematological manifestation of H1N1 has commonly been observed with leucopenia, neutropenia, and idiopathic thrombocytopenic purpura. Rarely, HLH has been observed [6].

HLH represents a severe hyperinflammatory condition with the major symptoms of prolonged fever, peripheral cytopenia affecting at least 2 lineages, hepatosplenomegaly, hypertriglyceridemia and/or hypofibrinogenemia, hyperferritinemia, decreased or absent natural killer cell activity, and high soluble interleukin 2 receptor serum levels and hemophagocytosis by activated macrophages. Five of these 8 criteria should be fulfilled to confirm diagnosis [1,2]. Our patient had prolonged fever, pancytopenia, hepatosplenomegaly, hyperferritinemia, hypofibrinogenemia, and hemophagocytosis at bone marrow aspiration and was diagnosed with HLH according to the criteria of HLH 2004 [1,2].
Our patient had prolonged fever, fatigue, myalgia, pneumonia, and prerenal insufficiency and diagnosed H1Nl influenza. The first reported case of H1N1 influenza virus-related HLH was in a 17-year-old female patient who completely recovered with steroid and oseltamivir treatment [3]. Following this case report, 23 more patients were reported of various ages between 2 months and 61 years old. In most of the cases, pancytopenia, hepatosplenomegaly, hyperferritinemia, hypofibrinogenemia, and hemophagocytosis at bone marrow aspiration were detected $[3,4,7,8,9,10,11,12]$. Oseltamivir and systemic steroid was the most commonly preferred treatment option. We diagnosed our patient with H1Nl virus-associated HLH. Besides oseltamivir, we also add IVIG to the treatment. On the third day of oseltamivir and second day of IVIG therapy, the patient became afebrile; oseltamivir therapy was stopped after 5 days of treatment.

HLH has high mortality rates if early diagnosis and treatment are delayed. In previously reported cases, only 5 out of 23 patients survived. In our case, treatment was started at the second day of hospitalization and a good response was achieved. In the first year of follow-up, hematologic and biochemical values remained normal, except for moderate splenomegaly and hyperferritinemia. To et al. reported prolonged viral load clearance and cytokine activation in H1N1 swine influenza virus infection [13]. We did not detect any obvious cause of splenomegaly in our patient. The splenomegaly and hyperferritinemia in our case may therefore be associated with prolonged inflammatory process and decreased viral load clearance. We report a very rare case of H1N1-related HLH in childhood, which was diagnosed early and successfully treated. If it is diagnosed late, H1N1associated HLH has very high mortality rates, but early diagnosis and treatment have favorable outcomes. It may also cause prolonged viral load clearance and cytokine response.

Key Words: Children, Hemophagocytic lymphohistiocytosis, Swine-origin influenza

\section{Conflict of Interest Statement}

The authors of this paper have no conflicts of interest, including specific financial interests, relationships, and/ or affiliations relevant to the subject matter or materials included.

\section{References}

1. Janka GE. Familial and acquired hemophagocytic lymphohistiocytosis. Annu Rev Med 2012;63:233-246.

2. Rouphael NG, Talati NJ, Vaughan C, Cunningham K, Moreira $\mathrm{R}$, Gould C. Infections associated with haemophagocytic syndrome. Lancet Infect Dis 2007;7:814-822.

3. Zheng Y, Yang Y, Zhao W, Wang H. Novel swine-origin influenza A (H1N1) virus-associated hemophagocytic syndrome--a first case report. Am J Trop Med Hyg 2010;82:743-745. 
4. Ozdemir H, Çiftçi E, Ince EU, Ertem M, Ince E, Doğru U. Hemophagocytic lymphohistiocytosis associated with 2009 pandemic influenza A (H1N1) virus infection. J Pediatr Hematol Oncol 2011;33:135-137.

5. Novel Swine-Origin Influenza A (H1N1) Virus Investigation Team, Dawood FS, Jain S, Finelli L, Shaw MW, Lindstrom S, Garten RJ, Gubareva LV, Xu X, Bridges CB, Uyeki TM. Emergence of a novel swine-origin influenza A (H1N1) virus in humans. N Engl J Med 2009;360:2605-2615.

6. Unal S, Gökçe M, Aytaç-Elmas S, Karabulut E, Altan I, Ozkaya-Parlakay A, Kara A, Ceyhan M, Cengiz AB, Tuncer M, Cetin M, Gümrük F. Hematological consequences of pandemic influenza H1Nl infection: a single center experience. Turk J Pediatr 2010;52:570-575.

7. Willekens C, Cornelius A, Guerry MJ, Wacrenier A, Fourrier F. Fulminant hemophagocytic lymphohistiocytosis induced by pandemic A (H1N1) influenza: a case report. J Med Case Rep 2011;5:280.

8. Katsumi A, Nishida T, Murata M, Terakura S, Shimada K, Saito S, Kobayashi M, Kodaira A, Shibata S, Oda I, Yagi T, Kiyoi H, Matsushita T, Kojima T, Naoe T. Virus-associated hemophagocytic syndrome caused by pandemic swine-origin influenza $\mathrm{A}(\mathrm{H} 1 \mathrm{~N} 1)$ in a patient after unrelated bone marrow transplantation. J Clin Exp Hematop 2011;51:63-65.

9. Asai N, Ohkuni Y, Matsunuma R, Iwama K, Otsuka Y, Kawamura Y, Motojima S, Kaneko N. A case of novel swine influenza A (H1N1) pneumonia complicated with virusassociated hemophagocytic syndrome. J Infect Chemother 2012;18:771-774.
10. Ur Rehman J, Wali G, Sayes NM, Maulawi A, Aslam M, Khalid I. Novel influenza A (H1N1) virus-induced hemophagocytosis: first case reported in Saudi Arabia. Ann Saudi Med 2012;32:86-89.

11. Beutel G, Wiesner O, Eder M, Hafer C, Schneider AS, Kielstein JT, Kühn C, Heim A, Ganzenmüller T, Kreipe HH, Haverich A, Tecklenburg A, Ganser A, Welte T, Hoeper MM. Virus-associated hemophagocytic syndrome as a major contributor to death in patients with 2009 influenza A (H1N1) infection. Crit Care 2011;15:80.

12. Harms PW, Schmidt LA, Smith LB, Newton DW, Pletneva MA, Walters LL, Tomlins SA, Fisher-Hubbard A, Napolitano LM, Park PK, Blaivas M, Fantone J, Myers JL, Jentzen JM. Autopsy findings in eight patients with fatal H1Nl influenza. Am J Clin Pathol 2010;134:27-35.

13. To KK, Hung IF, Li IW, Lee KL, Koo CK, Yan WW, Liu R, Ho KY, Chu KH, Watt CL, Luk WK, Lai KY, Chow FL, Mok T, Buckley T, Chan JF, Wong SS, Zheng B, Chen H, Lau CC, Tse H, Cheng VC, Chan KH, Yuen KY. Delayed clearance of viral load and marked cytokine activation in severe cases of pandemic H1N1 2009 influenza virus infection. Clin Infect Dis 2010;50:850-859. 